\title{
Analysis of Satellite City Readiness Effect towards Organization of Sport Events in South Sumatra Province
}

\author{
$1^{\text {st }}$ Pelliyezer Karo Karo \\ MICE \& Event Management Programme \\ Palembang Polytechnic of Tourism \\ South Sumatera, Indonesia \\ pelliyezer@poltekpar-palembang.ac.id \\ https://orcid.org/0000-0002-2462-5297
}

\author{
$2^{\text {nd }}$ Muhammad Iqbal \\ MICE \& Event Management Programme \\ Palembang Polytechnic of Tourism \\ South Sumatera, Indonesia \\ muhammadiqbaldjohan.mid@gmail.com
}

\author{
$3^{\text {rd }}$ Yayan Dian Fitriansyah \\ MICE \& Event Management Programme \\ Palembang Polytechnic of Tourism \\ South Sumatera, Indonesia \\ yayandianfitriansyah@gmail.com
}

\begin{abstract}
This research is conducted to determine the effect of satellite city readiness towards organizing sport events in the province of South Sumatra, where readiness is examined based on eight city liveable variables including physical city, environmental quality, accessibility, facilities, utilities, economy, social and bureaucracy. The model of data analysis was multiple linear regression analysis with the presentation of hypotheses carried out simultaneously and partially by using statistic software. The samples of the research were 118 both domestic and foreign tourists. The results showed that the eight variables in Banyuasin Regency and Ogan Ilir Regency simultaneously had a significant effect on dependent variable of organizing sport events in South Sumatra. Partially, research in Banyuasin Regency resulted in variable environmental and facility quality having a significant effect in organizing sport events in South Sumatra, while research in Ogan Ilir District results in variable accessibility and utility significantly influences the organization of sports events in South Sumatra.
\end{abstract}

Keywords: satellite city, liveable cities, sport event

\section{INTRODUCTION}

The tourism industry is projected to be the largest foreign exchange earner in Indonesia in 2019, surpassing the oil and gas, coal and palm oil sectors. This is in line with the idea of making tourism the core business of this country. Of the several types of tourism found in Indonesia, one that has great potential and is a national concern as one of the processes to achieve the goal of increasing community welfare is sports tourism, considering that this type of tourism is a type of tourism involving a wide variety of levels and community segmentation.

One example of the influence of sport events for public welfare is the Tour de Singkarak Sport Event, which in 2017 had a direct impact on the community economy (Direct Impact Economic Tourism) and high media value. Since 2013 the Amauri Sport Organization (ASO) has recommended the Tour de Singkarak to become a major championship in Asia because it can absorb more than one million viewers. after the implementation of the 9 years Tour de Singkarak there has been a positive growth in West Sumatra such as hotel growth from year to year. In 2014 there were 274 hotels, and homestays of 5588 rooms. In
2016 it increased to 339 hotels and homestays by 7799 rooms.

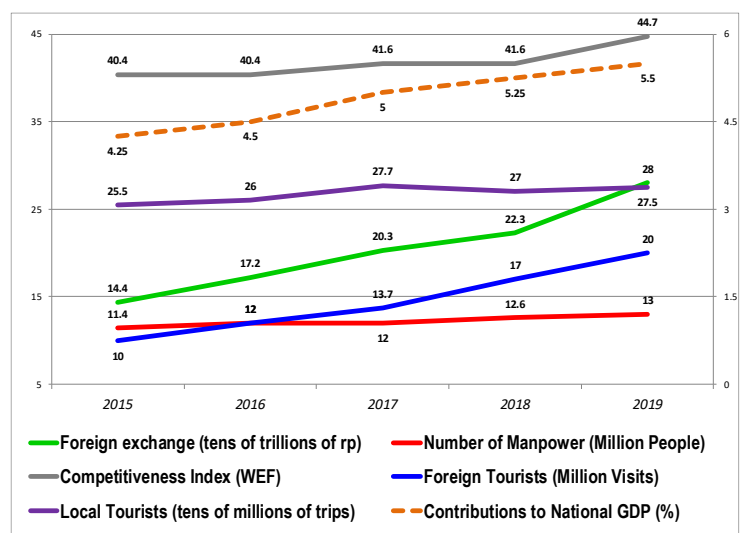

Figure 1. Performance Chart of Indonesian Tourism Sector Source: BPS, 2018 (IBM SPSS Statistics 22)

Another sport event was the International Tour de Banyuwangi Ijen where the Banyuwangi Regent Abdullah Azwar Anas stated that the International Tour de Banyuwangi Ijen was not merely an arena for sport tourism, but a consolidation tool that changed people's culture to the lowest level. The impact of the implementation of the Ijen International Tour de Banyuwangi, once the tourist arrival rate in 2014 was only 500 thousand people. Then it increased in the following year to 700 thousand until the implementation in 2017 had reached 4.3 million people.

Based on the example of the successful management of sport events in the two cities involving several cities around the main city namely Tour de Singkarak and Tour de Ijen Banyuwangi which through several regencies / cities as satellite cities, of course requires community readiness and infrastructure facilities in an area that meets international implementation standards Sport Event. It can be concluded that the success of the implementation of a Sport Event certainly must be supported by a safe and comfortable area and meet the standard indicators of the implementation of the Sport Event.

The support of satellite cities is defined as a small city on the edge of a large city, although it is an independent community, most of the population depends on life in a big 
city. Usually the inhabitants of this satellite city are commuters (supporting) of large cities. Of course the development of this city is very necessary to support the success of the sport event considering that South Sumatra Province, especially Palembang City as the main city to host the Mega Sport Events, the XVIII Games in August 2018, requires the readiness of various aspects of satellite cities around Palembang. In the research which is a supporting city from Palembang including Ogan Ilir Regency and Banyuasin Regency.

The city of Palembang, South Sumatra Province is one of the regions that has the potential to become a national and international sport event destination. It is based on the largest Sports Venue in Indonesia, namely Jakabaring Sport City which is an international standard sports complex that has some venues. They are Sriwijaya Stadium, Tennis Court Stadium, Athletic Stadium, Aquatic Stadium, GOR Ranau (Badminton) Building, GOR Dempo Building (Gymnastics), Arena Baseball and Softball, Shooting Range, Water Skiing Arena, Beach Volleyball Arena, Wall Climbing Arena, Roller Skating Arena, Petanque Arena, and Bowling Arena Center. So the question then arises, "Are the satellite cities of Palembang, namely Ogan Ilir and Banyuasin Regencies fully prepared to support the implementation of sport events in South Sumatra Province?" This is a basic idea in conducting research to analyze the influence of satellite city readiness in organizing sport events in the Province. South Sumatra.

\section{LITERATURE REVIEW}

\section{A. Previous Research}

The first research reference is the research conducted by Ulfi Nurfaedah in 2015, with the title of the study Analysis of the Role of Tangerang City as the Satellite City of Jakarta (case study: commuter transportation tangerang-jakarta ${ }^{[1]}$. Reference to the next research is entitled Determinants and Consequences of the Perceived Social Impact of a Sport Event. This study was written by Yuhei Inoue and Cody $\mathrm{T}$. Havard from Memphis University in the journal Sport of Management in 2014. This research focuses on the determinants and consequences of the social impact of sport events. With the survey method researchers managed to find the positive and negative effects of a sport event.

\section{B. Satellite City}

Satellite city is a form of urban settlement that is not only used for sleeping, but also able to contribute to the development of the region in the form of commodities, services and information. Viewed from the economic and social aspects, satellite cities have sufficient capacity to fulfill jobs for the population, also possible for residents in sub-urbanization areas. Meanwhile, sub-urbanization only acts as a recipient of commodities and as a supplier of labor both to big cities and to satellite cities.

A livable city or a Liveable city is a city that has succeeded in providing a decent opportunity for humans to live in it, Cities Alliance (2007) states "A successful city must balance social, economic and environmental needs: it has to respond to pressure from all sides ${ }^{[2]}$. A successful city should offer investors security, infrastructure (including water and energy) and efficiency. It should also put the forefront of all its planning activities. A successful city that recognizes its natural assets, its citizens and its environment.

There are eight eight Liveable cities variables according to the 2008 IAP Symposium. These variables are reference material and considerations in this study in determining a liveable city, with indicators as follows:

1. Physical city includes spatial planning, architecture, green open space, characteristics and characteristics of local culture.

2. Environmental quality includes city cleanliness and pollution levels.

3. Transportation-Accessibility includes public transportation, road quality, travel time to activities, pedestrians.

4. Facilities include health facilities, education, worship, recreation, city parks.

5. Utilities include clean water, electricity, and telecommunications.

6. The economy includes income levels, living costs, and investment friendliness.

7. Social includes public spaces, creative spaces, social interactions, crime, and the level of equality of citizens, citizen participation, and support for parents, people with disabilities, and pregnant women.

8. Bureaucracy includes strong leadership, policy support, legal certainty, government accountability, level of implementation of city plans, support for development programs, financial support.

\section{Sport event}

Sport events can be interpreted as events intended for the public with activities that involve physical exertion and skills in which individuals or teams compete against other people or people for entertainment and sports. Kaplanidou and $\operatorname{Vogt}^{[3]}$ states that sport events is tourism product that can vary in size, meaning that Sport Events can be national, international, organizing sports events or sports matches whether multi-event or single event, continuously and in certain times long time in Indonesia, multi sport event categories such as Sea Games, PON, Pomnas, Popnas, Porcanas, while single event categories such as National Championship Tae Kwon Do, and Badminton National Badminton to the village / sub-district level sporting events.

Kennedy (2009) ${ }^{[4]}$ says that an event organizer designs and develops a successful sport event, with the aim of gathering communities in one location and conducting several activities that have been arranged to obtain information or witness an event, while developing an activity that aims to unite the community/people in one location and carry out several activities that it has been arranged to get information or see an event, or target public targets so that they visit activities or events that have been made by an event organizer. In general, the success of a sport event 
organization as follows: attendance rate, enthusiasm rate, event emotion value, and series of Activity.

\section{Banyuasin Regency}

Banyuasin Regency is one of the districts in South Sumatra Province, which is a division of Musi Banyuasin Regency, formed under the Republic of Indonesia's Law No. 6 of 2002. The name of this district is derived from the name of the Banyuasin River, which crosses the territory of this district and the Musi Banyuasin Regency. The words of Banyuasin itself come from the Javanese term banyu (water) and salty. The area of Banyuasin Regency is $11,875 \mathrm{~km} 2$ where there are several tribes that settled in this district, including Java, Madura, Bugis, Bali and the native people of Banyuasin.

The boundary of the Banyuasin region surrounds $2 / 3$ of the city of Palembang, so that Banyuasin can be said to be the buffer zone of the provincial capital of South Sumatra. Many of the developments in the province of South Sumatra were carried out on the edge of the Banyuasin region, bordering the area of Palembang city in order to support development in Palembang, such as LRT facilities, schools, Tanjung Api-api port docks and the Banyuasin district government. 500 million per village program so that infrastructure can be realized directly touching the village people.

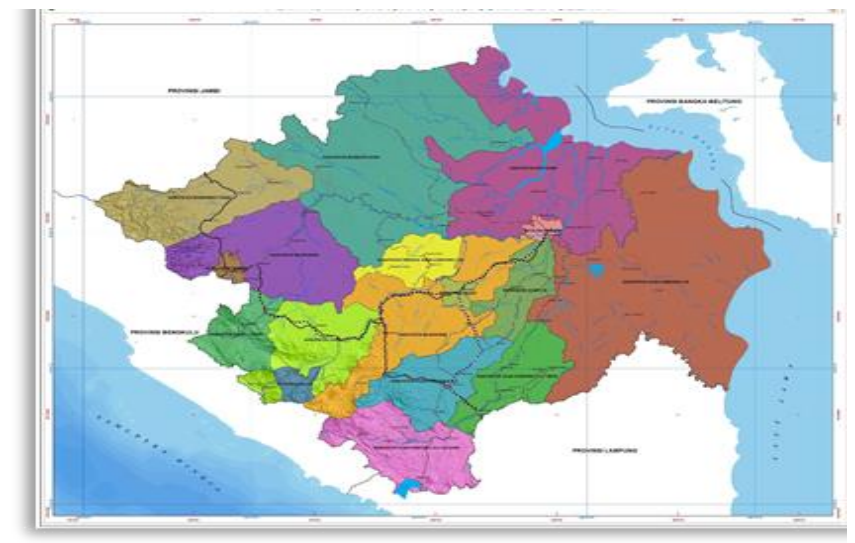

Figure 2. Administrative Map of the Province of South Sumatra Source: petatematikindo.wordpress.com

The implementation of e-government in Banyuasin has run quite well and is well known throughout Indonesia where ICT infrastructure development has been built since 2009 by connecting all agencies / offices / offices and sub-districts based on fiber optic networks. The awards achieved by Banyuasin District in the field of e-government included IOSA National champion, IDSA 2014, ICT with the main predicate, the best PEGI in Sumatra, so Banyuasin was used as a place of comparative study in the implementation of egovernment. In 2017 from 514 regencies / cities in Indonesia, the implementation of e-government in Banyuasin Regency was chosen as one of the smart areas by the Ministry of Communication and Information in collaboration with the Ministry of Home Affairs. In 2018 Indonesia was selected as the first winner of UP to represent Indonesia at the ASEAN ICT Award. Agriculture in Banyuasin is also a South Sumatra rice barn that accounts for 1.4 million tons of rice and continues to be increased with a target of 2 million tons of rice

\section{E. Ogan Ilir Regency}

Ogan Ilir Regency is also one of the districts in South Sumatra Province. Ogan Ilir is in the eastern Sumatra crossing route and its administrative center is located about $35 \mathrm{~km}$ from Palembang City. This regency is a division of Ogan Komering Ilir Regency. The legal basis is the Republic of Indonesia Law Number 37 of 2003 which was ratified on December 18, 2003. In 2013, the population of Ogan Ilir Regency reached 450,933 people or 117,783 families with population growth reaching 2 percent. The population in Ogan Ilir Regency comes from the Ogan Tribe with three sub-tribes, namely the Pegagan Ulu Tribe, the Penesak Tribe and the Pegagan Ilir Tribe, with the majority of the population working as Farmers.

From the results of interviews and observations in Ogan Ilir District, it was found that Ogan Ilir District was feasible to be a supporting city for the main city, namely the city of Palembang as a city of sport event organizers. Even from interviews, there are several sports that can be developed in this district, including soccer, volleyball, futsal, and swimming.

\section{RESEARCH}

This type of research is observational with a descriptive and analytical survey method. Descriptive research in this study used survey data because the data used were collected by interview techniques supported by a schedule questionnaire or interview guide. Based on the data collected, research will be conducted where this research is exploratory / explanatory. The research approach used is a qualitative approach and a quantitative approach. The qualitative approach emphasizes the development of narrative or descriptive textual on the phenomenon under study while quantitative research emphasizes numerical research on the phenomenon under study. The object location of the research was carried out in Banyuasin District and Ogan Ilir Regency, South Sumatra Province during June to August 2018.

\section{A. Population and sample}

The population in this study are tourists who are carrying out tourism activities in South Sumatra Province in general and at the locus of Banyuasin Regency and Ogan Ilir Regency in particular, which are based on the publication of the Central Sumatra Provincial Statistics Agency (BPS) data in July 2018, that in May 2018 tourists foreign countries number 696 people.

The sampling method used is to use probability sampling where each element of the population is given the opportunity to be withdrawn as a sample member. The sampling technique used is simple random sampling, because the population to be studied is relatively homogeneous. 
Determination of the number of samples in this study using the Slovin formula with e of $5 \%$, obtained the number of basic samples in this study were as many as 254 tourists in South Sumatra Province, assumed only around 70 percent of the basic sample who will conduct tourism activities in the Banyuasin Regency locus and Ogan Ilir District so that 177 is the main sample in this study which was chosen incidentally. In reality, from all expected research samples, only 118 respondents consisted of 66 respondents from Banyuasin Regency and 52 respondents from Ogan Ilir District who provided feedback with the results of questionnaires that could be quantified later.

\section{B. Tests of Instruments}

The validity and reliability test of the instrument in this study was carried out to 30 respondents outside of the respondents who were used as the study sample. For this study a total item correlation test will be carried out which is also called the item correlation test. The total item correlation test was conducted to test the internal validity of each question item in the questionnaire. In this test the total item score was correlated with the total score. To test item correlation can be used Product Moment correlation testing formula, since the number of question items for this study is relatively small, the correlation test conducted is the correlation test of the total corrected item (corrected item total correlation). The formula used is:

$$
r=\frac{\operatorname{rix}(S x)-S i}{\sqrt{\left[(S x)^{2}+(S i)^{2}-2(r i x)(S i)(S x)\right]}}
$$

Where,

rix $=$ total item correlation coefficient

$\mathrm{Si}=$ standard deviation score for each item in question

$\mathrm{Sx}=$ standard deviation total score

Test the validity of the instrument in the study by correlating each item score of each variable with the total score of the variable. The results of these calculations are then compared with the critical point ( $\mathrm{r}$ table) at a significant level of 5 percent. By using the degree of freedom $(\mathrm{df})=28$ and the level of significance for the two-way test, which is alpha $(\alpha)$ of 0.05 , the $r$ table value is 0.361 . From the results of the instrument validity test as shown in Table 1 shows that the calculated value of each item question variable> rtable value (0.361), which means that each item variable is declared valid or feasible to be used as a research questionnaire.

\section{Test of Classical Assumptions}

The data analysis model used in this study is a regression model. A good model is a model with minimal forecasting errors. Therefore, before the model is used it should be able to fulfill several assumptions commonly called classic assumptions, the classical assumptions that must be fulfilled are normality tests, multicollinearity tests and heteroscedasticity tests.
The normality test can be done by histrogram test, $\mathrm{P}$ plot value test, Chi Square test, Skewness and Kurtosis or Kolmogorov Smirnov test, to determine the residual normality of the regression model.
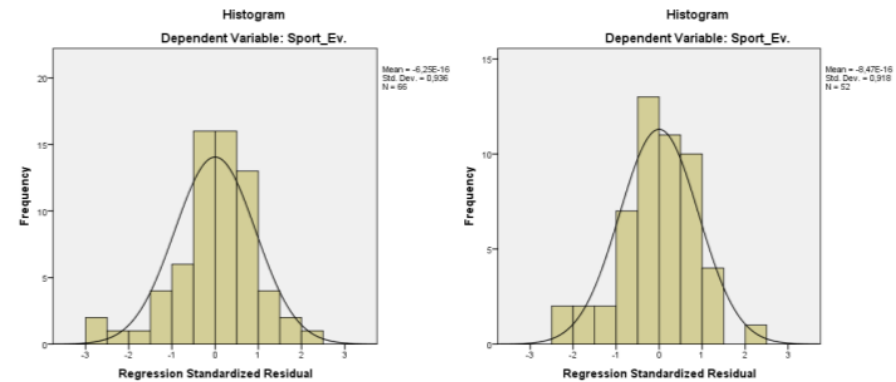

Figure 3. Histogram Graph of Normality Test Banyuasin Regency and Ogan Ilir Regency

Source: Research Results, 2018 (IBM SPSS Statistics 22)
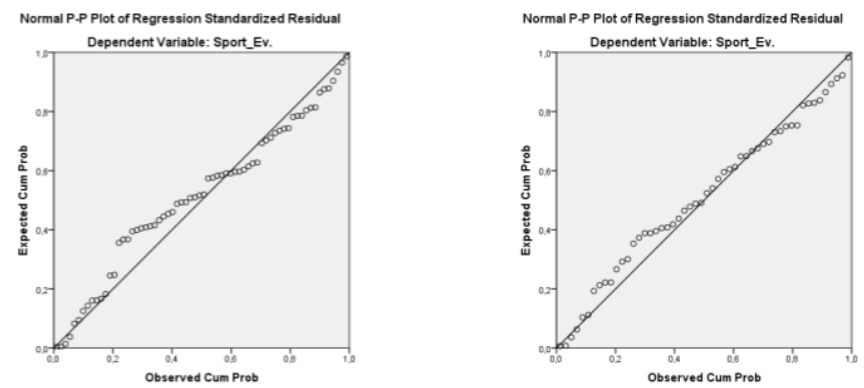

Figure 4. Normal Probability Chart Plot Normality Test Banyuasin Regency and Ogan Ilir Regency

Source: Research Results, 2018 (IBM SPSS Statistics 22)

Based on Figure 1 and Figure 2, the appearance of histogram and normal plot graphs shows that data or dots spread around the graph or diagonal line and follow the direction of the graph or diagonal line, it can be stated that the regression model meets the assumptions of normality.

\begin{tabular}{|c|c|c|}
\hline \multicolumn{3}{|c|}{ Banyuasin Regency } \\
\hline Kolmogorov Smirnov Test & Nilai Hitung & Nilai Tabel \\
\hline Most Extreme Differences $(D)$ & 0.135 & 0.167 \\
\hline Test Statistic (Z) & 0.135 & 0.547 \\
\hline Asymp. Sig. (2 tailed) & $0,005^{\mathrm{a}}$ & 0.109 \\
\hline \multicolumn{3}{|l|}{${ }^{a}$ Lilliefors significance correction } \\
\hline \multicolumn{3}{|c|}{ Ogan Ilir Regency } \\
\hline Kolmogorov Smirnov Test & Nilai Hitung & Nilai Tabel \\
\hline Most Extreme Differences $(D)$ & 0.093 & 0.189 \\
\hline Test Statistic (Z) & 0.093 & 0.535 \\
\hline Asymp. Sig. (2 tailed) & $0,200^{\mathrm{b}}$ & 0.109 \\
\hline${ }^{b}$ Lowerbound of true significant & & \\
\hline
\end{tabular}

To strengthen these results, in addition to graph analysis, researchers also used statistical tests, namely the Kolmogorov Smirnov (K-S) test which was intended to test the residual normality of the data. Based on Table 2, three analyzes can be conducted from the results of the study with the K-S test obtained, including: 
1. Most Extreme Differences are D statistic values in K-S test. In Banyuasin Regency, the absolute Dhitung value was obtained at 0.135 compared to the Dtable value with $\alpha=0.05$ and $n=66$ in the Critical Values for Kolmogorov-Smirnov Test statistical table known to be 0.167. Because Dhitung is smaller than Dtable, residual data can be stated in Banyuasin Regency with normal distribution. In Ogan Ilir Regency, the absolute Dhitung value was obtained at 0.093 compared to the Dtable value with $\alpha=0.05$ and $n=52$ was known as 0.189 . Because Dhitung is smaller than Dtable, residual data can be stated in Ogan Ilir District with normal distribution.

2. Kolmogorov Smirnov Test Statistic in Banyuasin Regency shows a calculated value of 0.135 compared to the value of Ztable by choosing the level of significance $\alpha=0.05$ and the two ends of the critical region (the two-sided critical region) in the normal standard distribution table of 0.547 . Because Zhitung is smaller than Ztable, residual data can be stated in Banyuasin Regency with normal distribution. The Kolmogorov Smirnov Statistic Test in Ogan Ilir Regency shows a calculated value of 0.095 compared to the Ztable value by choosing the level of significance $\alpha=0.05$ and the two ends of the critical region (the two-sided critical region) in the normal standard distribution table of 0.535 . Because Zhitung is smaller than Ztable, residual data can be stated in Ogan Ilir District with normal distribution.

3. Asymptotic significance 2 tailed is a probability value test to ensure that the observed distribution will not significantly deviate from the expected distribution at both ends of the two tailed distribution. In Banyuasin Regency, the value of (F (x) -S (x) oleh obtained by 0.005 compared to the lilliefors table value with $\alpha=$ 0.05 and $\mathrm{df}=66$ is known to be 0.109 . Because the value of $(F(x)-S(x) \square$ is smaller than the lilliefors table value, residual data can be stated in Banyuasin District with normal distribution. Whereas in Ogan Ilir Regency, the value of (F (x) -S (x) oleh was obtained at 0.200 compared to the significance value of $p$ value $\alpha=$ 0.05 , so that residual data in Ogan Ilir District were normally distributed, at the lowest level of significance.

Multicollinearity test is to see whether or not there is a high correlation between independent variables in a multiple linear regression model. If there is a high correlation between the independent variables, the relationship between the independent variables to the dependent variable becomes disturbed.

TABLE 3. TABLE OF VIF AND TOLERANCE OF MULTICOLLINEARITY TEST BANYUASIN REGENCY AND OGAN ILIR REGENCY

\begin{tabular}{lrrrrr}
\multirow{2}{*}{\begin{tabular}{c}
\multirow{2}{*}{ Variabel } \\
\end{tabular}} & \multicolumn{3}{c}{ Banyuasin Regency } & \multicolumn{3}{c}{ Ogan llir Regency } \\
\cline { 2 - 6 } & Tolerance & \multicolumn{1}{c}{ VIF } & Tolerance & \multicolumn{1}{c}{ VIF } \\
\hline Physic of City & .801 & 1.248 & .349 & 2.869 \\
\hline Quality of Environment & .442 & 2.264 & .889 & 1.125 \\
\hline Accessibility & .425 & 2.353 & .658 & 1.521 \\
\hline Amenities & .629 & 1.589 & .877 & 1.140 \\
\hline Utilities & .383 & 2.608 & .430 & 2.325 \\
\hline Economy & .667 & 1.498 & .769 & 1.301 \\
\hline Social & .331 & 3.024 & .490 & 2.042 \\
\hline Bureaucracy & .514 & 1.945 & .715 & 1.399 \\
\hline ree Research Results, 2018 (IBM SPSS Statistics 22)
\end{tabular}

Source: Research Results, 2018 (IBM SPSS Statistics 22)
Based on Table 3. shows that the Tolerance value is not less than 0.10 which means there is no correlation between the independent variables. The results of the calculation of the Variance Inflation Factor (VIF) value also show the same thing there is not one independent variable that has a VIF value of more than 10 . So it can be concluded that there is no multicolonity between independent variables in the regression model in the study with Banyuasin Regency and Ogan Ilir Regency locus.

Heteroscedasticity test aims to test whether in the regression model variance from residual inequality occurs one observation to another observation. If the residual variance from one observation to another observation remains, then it is called homoskedasticity and if it is different it is called heteroscedasticity. Detection of heteroscedasticity can be done using the scatterplot method.

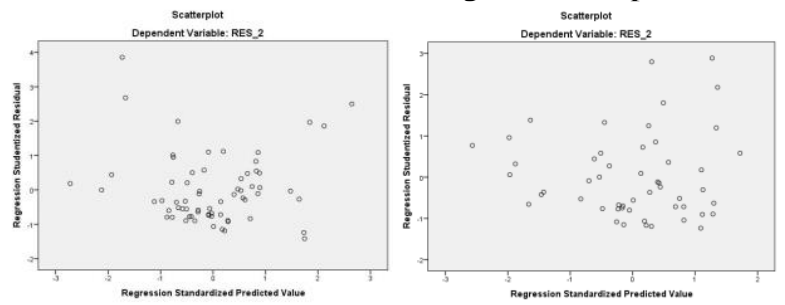

Figure 5. Scatterplot Graph of Heteroscedasticity Test Banyuasin Regency and Ogan Ilir Regency

Source: Research Results, 2018 (IBM SPSS Statistics 22)

Based on Figure 5 shows that the points contained in the image spread and did not form a particular pattern such as wavy or forming a line, this means that the regression model in this study did not occur heteroscedasticity but homoskedasticity.

To strengthen the results of the research test, the symptoms of heteroscedasticity were also tested using the Glejser test, namely by resetting absolute residual values to independent variables. Heteroscedasticity with the Glejser test does not occur if none of the independent variables are statistically significant affecting the dependent variable Ut absolute value (AbsUt).

TABle 4. GLEJSER TEST TABles FOR HETEROSCEDASTICITY TESTS BANYUASIN REGENCY AND OGAN ILIR REGENCY

\begin{tabular}{|l|c|c|}
\multicolumn{1}{c}{ Variabel } & Sig. Banyuasin Reg. Sig. Ogan llir Reg. \\
\hline Physic of City & .817 & .882 \\
\hline Quality of Environmen & .668 & .614 \\
\hline Accessibility & .499 & .580 \\
\hline Amenities & .177 & .961 \\
\hline Utilities & .602 & .996 \\
\hline Economy & .098 & .378 \\
\hline Social & .776 & .696 \\
\hline Bureaucracy & .385 & .617 \\
\hline
\end{tabular}

Source: Research Results, 2018 (IBM SPSS Statistics 22)

Based on Table 4. shows that none of the independent variables statistically significant affect the dependent variable Ut Absolute Value (AbsUt). This can be seen from the probability of its significance (Sig.) Above the confidence level of 5 percent. So it can be concluded that the regression model in this study did not occur with heteroscedasticity. 


\section{DATA ANALYSIS}

\section{A. Descriptive Analysis}

Descriptive analysis is an activity to deduce basic data in large numbers so that the results can be interpreted. Setting, sorting or manipulating data can provide descriptive information that will answer questions in the problem definition. In this study, respondents were divided into five characteristics, based on age, gender, marital status, recent education and tourist categories.

\begin{tabular}{|c|c|c|c|c|c|c|c|c|}
\hline \multirow[b]{2}{*}{ Description } & \multicolumn{4}{|c|}{ Banyuasin Regency } & \multicolumn{4}{|c|}{ Ogan Ilir Regency } \\
\hline & Min. & Max. & Mean & $\begin{array}{c}\text { Std. } \\
\text { Deviati } \\
\text { on }\end{array}$ & Min. & Max. & Mean & $\begin{array}{c}\text { Std. } \\
\text { Deviati } \\
\text { on }\end{array}$ \\
\hline Age & 27 & 56 & 40.30 & 9.009 & 25 & 51 & 37.75 & 7.289 \\
\hline Sex & 1 & 2 & 1.27 & .449 & 1 & 2 & 1.29 & .457 \\
\hline Marrital Status & 1 & 2 & 1.21 & .412 & 1 & 2 & 1.23 & .425 \\
\hline Education & 1 & 3 & 2.48 & .662 & 1 & 3 & 2.44 & .669 \\
\hline Tourist Category & 1 & 2 & 1.61 & .492 & 1 & 2 & 1.29 & .457 \\
\hline
\end{tabular}

Source: Research Results, 2018 (IBM SPSS Statistics 22)

Based on the analysis from Table 5, some basic conclusions from the respondents can be obtained, namely:

1. The age interval of respondents in Banyuasin Regency is in 27-56 years, with an average age of 40 years, while the age interval of respondents in Ogan Ilir Regency is in 25-51 years with an average age of 37-38 years.

2. Respondents in Banyuasin and Ogan Ilir Regencies were dominated by male tourists and the average respondent from each locus was married.

3. Both the respondents in Banyuasin District and Ogan Ilir have the latest education closer to the undergraduate level.

4. Respondents in Banyuasin Regency are predominantly foreign tourists while respondents in Banyuasin Regency are dominated by domestic tourists.

\section{B. Analysis of Multiple Linear Regression}

This study examines how far a dependent variable is in this case is the implementation of sport events which are influenced by several independent variables, namely in this study eight liveable cities variables consisting of the city physical, environmental quality, accessibility, facilities, utilities, economy, social, and bureaucracy then the analytical model that will be used to examine this relationship is the multiple linear regression model. In a multiple linear regression analysis a regression equation will be developed which is a formula that looks for the value of the dependent variable of the known independent variable values, namely:

$$
\begin{gathered}
\mathrm{Y}=\mathrm{a}+\mathrm{b} 1 \mathrm{X} 1+\mathrm{b} 2 \mathrm{X} 2+\mathrm{b} 3 \mathrm{X} 3+\mathrm{b} 4 \mathrm{X} 4+\mathrm{b} 5 \mathrm{X} 5 \\
+\mathrm{b} 6 \mathrm{X} 6+\mathrm{b} 7 \mathrm{X} 7+\mathrm{b} 8 \mathrm{X} 8+\mathrm{e}
\end{gathered}
$$

Where:

$$
\begin{array}{ll}
\mathrm{Y} & =\text { Organizing a Sport Event } \\
\mathrm{a} & =\text { Constant } \\
\mathrm{X} 1 & =\text { Physical City } \\
\mathrm{X} 2 & =\text { Environmental Quality } \\
\mathrm{X} 3 & =\text { Accessibility } \\
\mathrm{X} 4 & =\text { Facilities } \\
\mathrm{X} 5 & =\text { Utility } \\
\mathrm{X} 6 & =\text { Economy } \\
\mathrm{X} 7 & =\text { Social } \\
\mathrm{X} 8 & =\text { Bureaucracy } \\
\mathrm{e} & =\text { epsilon or variables not examined }
\end{array}
$$

\begin{tabular}{|c|c|c|c|c|c|c|}
\hline \multirow[b]{2}{*}{ Mod } & & \multicolumn{2}{|c|}{ Unstandardized Coefficients } & \multirow{2}{*}{$\begin{array}{c}\begin{array}{c}\text { Standardized } \\
\text { Coefficients }\end{array} \\
\text { Beta }\end{array}$} & \multirow[b]{2}{*}{$t$} & \multirow[b]{2}{*}{ Sig. } \\
\hline & & $\mathrm{B}$ & Std. Error & & & \\
\hline \multirow[t]{9}{*}{1} & (Constant) & .171 & .619 & & .277 & .783 \\
\hline & Fisik_Kota &, 007 & .047 & .008 & 147 & .884 \\
\hline & Kualitas_Lk. &, 712 & .071 &, 765 & 10,068 &, 000 \\
\hline & Aksesbilitas &, 056 & .064 & .068 &, 877 & ,384 \\
\hline & Fasilitas & 191 & .059 & .206 & 3,229 &, 002 \\
\hline & Utilitas & 037 & .057 & .053 & 649 & .519 \\
\hline & Ekonomi & -.064 & .050 &,- 078 & $-1,264$ & .211 \\
\hline & Sosial & .020 & .065 & .027 & 308 & .759 \\
\hline & Birokrasi &,- 003 & .060 &,- 003 &,- 049 & .961 \\
\hline
\end{tabular}

\begin{tabular}{|c|c|c|c|c|c|c|}
\hline \multirow[b]{2}{*}{ Mod } & & \multicolumn{2}{|c|}{ Unstandardized Coefficients } & \multirow{2}{*}{$\begin{array}{c}\begin{array}{c}\text { Standardized } \\
\text { Coefficients }\end{array} \\
\text { Beta } \\
\end{array}$} & \multirow[b]{2}{*}{$t$} & \multirow[b]{2}{*}{ Sig. } \\
\hline & & $\mathrm{B}$ & Std. Error & & & \\
\hline \multirow[t]{9}{*}{1} & (Constant) & -.237 &, 950 & &,- 249 & 804 \\
\hline & Fisik_Kota & -.006 & .093 & -.007 & -.069 & 945 \\
\hline & Kualitas_Lk. &,- 019 &, 063 &,- 020 &,- 302 &, 764 \\
\hline & Aksesbilitas &, 333 &, 076 &, 335 & 4,363 & .000 \\
\hline & Fasilitas &,- 015 &, 058 &,- 017 &,- 255 & 800 \\
\hline & Utilitas &, 634 &, 096 & .626 & 6,584 &, 000 \\
\hline & Ekonomi & -.053 &, 066 &,- 057 &,- 808 & .424 \\
\hline & Sosial & .117 &, 086 & .120 & 1,352 & .184 \\
\hline & Birokrasi & .001 & .059 & .001 & .012 & .990 \\
\hline
\end{tabular}

Multiple linear regression analysis aims to determine how much influence the independent variables cause the dependent variable to occur. Analysis of research data was carried out at a confidence level of 95 percent with an error tolerance (alpha) of 5 percent.

TABLE 6. TEST OF SIGINIFIKANSI INDIVIDUAL PARAMETERS (TEST STATISTICS T) BANYUASIN REGENCY AND OGAN ILIR REGENCY Coefficients $^{\mathrm{a}}$

a. Dependent Variable: Sport_Ev.

Coefficients $^{a}$

a. Dependent Variable: Sport_Ev.

Source: Research Results, 2018 (IBM SPSS Statistics 22)

Based on Table 6 the linear regression equation model was obtained in this study with the Banyuasin Regency locus namely:

$$
\begin{array}{r}
Y=0,171+0,007 X_{1}+0,712 X_{2}+0,056 X_{3}+0,191 X_{4} \\
+0,037 X_{5}-0,064 X_{6}+0,02 X_{7}-0,003 X_{8}
\end{array}
$$

Means:

1. Based on this equation, if $\mathrm{X} 1, \mathrm{X} 2, \mathrm{X} 3, \mathrm{X} 4, \mathrm{X} 5, \mathrm{X} 5$, $\mathrm{X} 7, \mathrm{X} 8=0$, then the $\mathrm{Y}$ value is 1.71 . This means that if the implementation of a sport event is not influenced by the eight physical variables of the city, environmental quality, accessibility, facilities, utilities, economy, social and bureaucracy in 
Banyuasin Regency, then the value of the sport event is 0.171 units.

2. Constant value of 0.171 can be interpreted that the average contribution of other variables outside the model has a positive impact on the implementation of sport events.

3. The equation shows that if $\mathrm{X} 1, \mathrm{X} 2, \mathrm{X} 3, \mathrm{X} 4, \mathrm{X} 5$, $\mathrm{X} 5, \mathrm{X} 7, \mathrm{X} 8$ are added by one unit then the sport event will increase by $0.007 \mathrm{X} 1,0.712 \mathrm{X} 2,0.056$ $\mathrm{X} 3,0.191 \mathrm{X} 4,0.037 \mathrm{X} 5,-0.064 \mathrm{X} 6,0.02 \mathrm{X} 7$ and $0.003 \mathrm{X} 8$ units.

Based on Table 6 also obtained a linear regression model of research with the locus of Ogan Ilir Regency, namely:

$$
\begin{gathered}
\mathrm{Y}=-0.237-0.006 \mathrm{X} 1-0.019 \mathrm{X} 2+0.333 \mathrm{X} 3-0.015 \mathrm{X} 4 \\
+0,634 \mathrm{X} 5-0,053 \mathrm{X} 6+0,117 \mathrm{X} 7+0,001 \mathrm{X} 8
\end{gathered}
$$

The static test $\mathrm{F}$ basically shows whether all the independent or free variables included in the model have a joint effect on the dependent or bound variables. In this test also means that all independent variables simultaneously are significant explanations of the dependent variable. The F test aims to determine the effect of independent variables simultaneously on the dependent variable with a 95 percent confidence level ( $\alpha=5$ percent).

To test the effect of satellite city readiness based on liveable cities theory simultaneously on the implementation of sport events in South Sumatra Province, the F Statistic test ( $F$ test) was used. If the value of Fcount $>$ value of Ftable, then Ho is rejected and $\mathrm{Ha}$ is accepted. Conversely, if the value of $\mathrm{F}$ count <Ftable value, then Ho is accepted and $\mathrm{Ha}$ is rejected.

TABle 7. Simultaneous SiginifiKansi TeSt (F StATISTIC TEST) BANYUASIN REGENCY AND OGAN ILIR REGENCY ANOVA $^{a}$

\begin{tabular}{|ll|r|r|r|r|c|}
\hline Model & & \multicolumn{1}{|c|}{$\begin{array}{c}\text { Sum of } \\
\text { Squares }\end{array}$} & \multicolumn{1}{c|}{$\mathrm{df}$} & Mean Square & $\mathrm{F}$ & Sig. \\
\hline 1 & Regression & 103,916 & 8 & 12,990 & 41,891 &, $000^{\mathrm{b}}$ \\
& Residual & 17,675 & 57 &, 310 & & \\
& Total & 121,591 & 65 & & & \\
\hline
\end{tabular}

a. Dependent Variable: Sport_Ev.

b. Predictors: (Constant), Birokrasi, Fasilitas, Utilitas, Fisik_Kota, Ekonomi, Kualitas_Lk.,

\begin{tabular}{|c|c|c|c|c|c|c|}
\hline \multicolumn{7}{|c|}{ ANOVA $^{\text {a }}$} \\
\hline \multicolumn{2}{|c|}{ Model } & $\begin{array}{l}\text { Sum of } \\
\text { Squares }\end{array}$ & df & Mean Square & $\mathrm{F}$ & Sig. \\
\hline \multirow[t]{3}{*}{1} & Regression & 95,657 & 8 & 11,957 & 26,821 &, $000^{\mathrm{b}}$ \\
\hline & Residual & 19,170 & 43 &, 446 & & \\
\hline & Total & 114,827 & 51 & & & \\
\hline
\end{tabular}
Aksesbilitas, Sosial

a. Dependent Variable: Sport_Ev.

b. Predictors: (Constant), Birokrasi, Kualitas_Lk., Aksesbilitas, Ekonomi, Fasilitas, Sosial, Utilitas, Fisik_Kota

Source: Research Results, 2018 (IBM SPSS Statistics 22 and processed)

Based on Table 7 shows that the locus of Banyuasin Regency has a Fcount of 41.891 and a significance level of 0.000 whereas by using a confidence interval of 95 percent or $\alpha=0.05, \mathrm{df} 1=8, \mathrm{df} 2=57$ the Ftable value is 2.11 . By comparing the value of Fcount and Ftable, it is known that Fcount $(41,891)>$ Ftable $(2,11)$ and the value of Sig. $(0,000)$ $<\alpha(0,05)$, meaning that Ho is rejected, and Ha is accepted, which means that simultaneously the liveable variable of Banyuasin Regency which consists of physical city, environmental quality, accessibility, facilities, utilities, economy, social and influential bureaucracy positive and very significant (high significant) towards the implementation of sport events in the Province of South Sumatra.

Table 7 also shows that the locus of Ogan Ilir Regency has a Fcount of 26.821 and a significance level of 0,000 whereas using a confidence interval of 95 percent or $\alpha=$ 0.05 , df $1=8$, df $2=43$ the Ftable value is 2,16 . By comparing the value of Fcount and Ftable, it is known that Fcount $(26,821)>$ Ftable $(2,16)$ and the value of Sig. $(0,000)$ $<\alpha(0,05)$, means that Ho is rejected, and $\mathrm{Ha}$ is accepted, which also means simultaneously the liveable variable of Ogan Ilir Regency which consists of physical city, environmental quality, accessibility, facilities, utilities, economy, social and bureaucracy has a positive and very significant effect on the implementation of sport events in South Sumatra Province.

The $t$ statistic test basically shows how far the influence of one explanatory variable or independent individually in explaining the variation of the dependent variable. The $t$ test in this study was conducted to show whether the eight independent variables of city physical, environmental quality, accessibility, facilities, utilities, economics, social, and bureaucracy had a significant influence on the dependent variable in the implementation of sport events.

To test the effect of liveable cities factors consisting of commitment, city physical, environmental quality, accessibility, facilities, utilities, economy, social and bureaucracy partially towards the implementation of sport events in the Province of South Sumatra, Statistics t test $(\mathrm{t}$ test) was used. If the value of tcount> value $t$ table, then Ho is rejected and $\mathrm{Ha}$ is accepted. Conversely, if the value of tcount <value $\mathrm{t}$ table, then Ho is accepted and Ha is rejected. This statistic test is based on the results of the research in Table 6. which shows at the Banyuasin Regency locus, the tcount of each independent variable in this study, which will be compared with the ttable value using a 95 percent confidence interval or $\alpha=0.05$ and $\mathrm{df}=64$, the ttable value is 1.998 .

The results of partial hypothesis testing indicate that the city physical variable (X1) has:

1. The value of tcount of 0.147 is smaller than the value of table which means that the physical variable of the city does not affect the implementation of sport events.

2. The significance value of 0.884 is greater than the value of $\alpha$, which means that the physical variables of the city are not significant for the implementation of sport events, where if the physical variables of the city are increased by one unit, the sport event will increase by 0.007 units. 
This means that the decision is that Hol is accepted and Ha1 is rejected, meaning that partially the physical variables of the city locus of Banyuasin Regency have no significant effect on the implementation of sport events in the Province of South Sumatra.

The results of partial hypothesis testing indicate that the environment quality variable (X2) has:

1. The tcount of 10.068 is greater than the value of $t$ table which means that the variable quality of the environment has a positive effect on the implementation of sport events.

2. The significance value of 0,000 is smaller than the value of $\alpha$, which means that the variable environmental quality has a significant effect on the implementation of sport events, where if the variable quality of the environment is increased by one unit, the implementation of sport events will increase by 0.712 units.

This means that the decision is $\mathrm{Ho} 2$ rejected and $\mathrm{Ha} 2$ accepted, meaning that partially the locus quality quality variable of Banyuasin Regency has a significant effect on the implementation of sport events in South Sumatra Province.

The results of partial hypothesis testing indicate that the accessibility variable (X3) has:

1. The tcount of 0.877 is smaller than the table value, which means that the accessibility variable does not affect the implementation of sport events.

2. The significance value of 0.384 is greater than the value of $\alpha$, which means that the accessibility variable is not significant for the implementation of sport events, where if the accessibility variable is increased by one unit, the sport event will increase by 0.056 units.

This means that the decision is that Ho3 is accepted and Ha3 is rejected, meaning that partially the variable locus accessibility of Banyuasin Regency has no significant effect on the implementation of sport events in the Province of South Sumatra.

The results of partial hypothesis testing indicate that the facility variable (X4) has:

1. The value of tcount is 3.229 greater than the value of table which means that the facility variable has a positive effect on the implementation of sport events.

2. The significance value of 0.002 is smaller than the value of $\alpha$, which means that the facility variable has a significant effect on the implementation of sport events, where if the facility variable is increased by one unit, the implementation of sport events will increase by 0.191 units.

This means that the decision is Ho4 rejected and Ha4 accepted, meaning that partially the variable locus facility of Banyuasin Regency has a significant effect on the implementation of sport events in the Province of South Sumatra.
The results of partial hypothesis testing indicate that the utility variable (X5) has:

1. The value of tcount of 0.649 is smaller than the value of table which means the utility variable does not affect the implementation of sport events.

2. The significance value of 0.519 is greater than the value of $\alpha$, which means that the utility variable is not significant for the implementation of sport events, where if the utility variable is increased by one unit, the implementation of sport events will increase by 0.037 units.

This means that the decision is Ho5 accepted and Ha5 rejected, meaning that partially the utility locus variable of Banyuasin Regency has no significant effect on the implementation of sport events in South Sumatra Province.

The results of partial hypothesis testing indicate that economic variables (X6) have:

1. The value of tcount of -1.264 is smaller than the value of table which means that the economic variable does not affect the implementation of sport events.

2. Significance value of 0.211 is greater than the value of $\alpha$, which means that the economic variable is not significant for the implementation of sport events, where if the economic variable is increased by one unit, the implementation of sport events will increase by -0.064 units.

This means that the decision is Ho6 accepted and Ha6 rejected, meaning that partially the economic variable locus of Banyuasin Regency has no significant effect on the implementation of sport events in South Sumatra Province.

The results of partial hypothesis testing indicate that social variables $(\mathrm{X} 7)$ have:

1. The value of tcount of 0.308 is smaller than the value of $t$ table, which means that the social variable does not affect the implementation of sport events.

2. Significance value of 0.759 is greater than the value of $\alpha$, which means that the social variable is not significant for the implementation of sport events, where if social variables are increased by one unit, the implementation of sport events will increase by 0.02 units.

This means that the decision is $\mathrm{Ho} 7$ accepted and Ha7 rejected, meaning that partially the social variable locus of Banyuasin Regency has no significant effect on the implementation of sport events in South Sumatra Province.

The results of partial hypothesis testing indicate that the bureaucratic variable $(\mathrm{X} 8)$ has:

1. The value of tcount of -0.049 is smaller than the value of ttabel, which means that the bureaucratic variable does not affect the implementation of sport events.

2. Significance value of 0.961 is greater than the value of $\alpha$, which means that the bureaucratic variable is not significant for the implementation of sport events, where if the bureaucratic variable is increased 
by one unit, the implementation of sport events will increase by -0.003 units.

This means that the decision is accepted Ho8 and Ha8 rejected, meaning that partially Banyusin Regency locus bureaucracy variable does not significantly influence the implementation of sport events in South Sumatra Province.

Based on Table 6 shows for the locus of Ogan Ilir Regency, the tcount of each independent variable in this study, will be compared with the ttable value using a confidence interval of 95 percent or $\alpha=0.05$ and $\mathrm{df}=50$, then obtained a ttable value of 2,009.

The results of partial hypothesis testing indicate that the city physical variable (X1) has:

1. The value of tcount of -0.069 is smaller than the value of $\mathrm{t}$ table, which means that the physical variable of the city does not affect the implementation of sport events.

2. The significance value of 0.945 is greater than the value of $\alpha$, which means that the physical variables of the city are not significant for the implementation of sport events, where if the physical variables of the city are increased by one unit, the sport event will increase by -0.006 units.

This means that the decision is that Hol is accepted and Ha1 is rejected, meaning that partially the physical variables of the city locus of Ogan Ilir Regency have no significant effect on the implementation of sport events in the Province of South Sumatra.

The results of partial hypothesis testing indicate that the environment quality variable (X2) has:

1. The t-count value is -0.302 smaller than the t-table value, which means that the variable quality of the environment does not affect the implementation of sport events.

2. The significance value of 0.764 is greater than the value of $\alpha$, which means that the environment quality variable is not significant for the implementation of sport events, where if the city physical variables are increased by one unit, the sport event will increase by -0.019 units.

This means that the decision is $\mathrm{Ho} 2$ accepted and $\mathrm{Ha} 2$ rejected, meaning that partially the environment quality variable locus of Ogan Ilir Regency has no significant effect on the implementation of sport events in the Province of South Sumatra.

The results of partial hypothesis testing indicate that the accessibility variable (X3) has:

1. The value of tcount of 4.363 is greater than the value of $\mathrm{t}$ table, which means that the variable accessibility has a positive effect on the implementation of sport events.

2. The significance value of 0,000 is smaller than the value of $\alpha$, which means that accessibility variables have a significant effect on the implementation of sport events, where if the accessibility variable is increased by one unit, the implementation of sport events will increase by 0.333 units.

This means that the decision is $\mathrm{Ho} 3$ rejected and $\mathrm{Ha} 3$ is accepted, meaning that partially the locus accessibility variable Ogan Ilir Regency has a significant effect on the implementation of sport events in South Sumatra Province.

The results of partial hypothesis testing indicate that the facility variable $(\mathrm{X} 4)$ has:

1. The value of tcount of -0.255 is smaller than the value of table which means that the facility variable does not affect the implementation of sport events.

2. The significance value of 0.800 is greater than the value of $\alpha$, which means that the utility variable is not significant for the implementation of sport events, where if the facility variable is increased by one unit, the sport event will increase by -0.015 units.

This means that the decision is Ho4 accepted and Ha4 rejected, meaning that partially the Ogan Ilir Regency locus facility variable has no significant effect on the implementation of sport events in South Sumatra Province.

The results of partial hypothesis testing indicate that the utility variable (X5) has:

1. The tcount of 6.584 is greater than the value of $t$ table, which means the utility variable has a positive effect on the implementation of sport events.

2. The significance value of 0,000 is smaller than the value of $\alpha$, which means that the utility variable has a significant effect on the implementation of sport events, where if the utility variable is increased by one unit, the implementation of sport events will increase by 0.634 units.

This means that the decision is Ho5 rejected and Ha5 accepted, meaning that partially the Ogan Ilir Regency locus utility variable has a significant effect on the implementation of sport events in South Sumatra Province.

The results of partial hypothesis testing indicate that economic variables (X6) have:

1. The t-count is -0.808 smaller than the t-table value, which means that the economic variable does not affect the implementation of sport events.

2. Significance value of 0.424 is greater than the value of $\alpha$, which means that the economic variable is not significant for the implementation of sport events, where if the economic variable is increased by one unit, the implementation of sport events will increase by -0.053 units.

This means that the decision is Ho6 accepted and Ha6 rejected, meaning that partially the economic variable of the locus of Ogan Ilir Regency has no significant effect on the implementation of sport events in the Province of South Sumatra.

The results of partial hypothesis testing indicate that social variables $(\mathrm{X} 7)$ have: 
1. The value of tcount of 1.352 is smaller than the value of $t$ table, which means that the social variable does not affect the implementation of sport events.

2. Significance value of 0.184 is greater than the value of $\alpha$, which means that the social variable is not significant for the implementation of sport events, where if social variables are increased by one unit, the implementation of sport events will increase by 0.117 units.

This means that the decision is Ho7 accepted and Ha7 rejected, meaning that partially the social variable locus of Ogan Ilir Regency has no significant effect on the implementation of sport events in the Province of South Sumatra.

The results of partial hypothesis testing indicate that the bureaucratic variable (X8) has:

1. The value of tcount of 0.012 is smaller than the value of $\mathrm{t}$ table, which means that the bureaucratic variable does not affect the implementation of sport events.

2. The significance value of 0.990 is greater than the value of $\alpha$, which means that the bureaucratic variable is not significant for the implementation of sport events, where if the bureaucratic variable is increased by one unit, the sport event will increase by 0.001 units

This means that the decision is $\mathrm{Ho} 8$ accepted and $\mathrm{Ha} 8$ rejected, meaning that partially the Ogan Ilir Regency locus bureaucracy variable has no significant effect on the implementation of sport events in South Sumatra Province.

The coefficient of determination is to measure the ability of independent variables that explain the effect on the dependent variable. Where to consider the fact that the magnitude of the degree of freedom decreases with respect to the increase in the independent variable or explanatory variable in the regression, also calculated R2 adjusted for adjusted R2 as follows:

$$
\text { Adjusted } R^{2}=1-1\left(1-R^{2}\right)\left[\frac{n-1}{n-k}\right]
$$

\section{Where:}

$\mathrm{n}=$ number of observations or sample data

$\mathrm{k}=$ number of parameters or coefficients estimated.

TABLE 8. DETERMINATION COEFFICIENT TEST BANYUASIN REGENCY AND OGAN ILIR REGENCY

\section{Model Summary}

\begin{tabular}{|l|l|r|r|r|}
\hline Model & R & R Square & $\begin{array}{c}\text { Adjusted R } \\
\text { Square }\end{array}$ & $\begin{array}{c}\text { Std. Error of } \\
\text { the Estimate }\end{array}$ \\
\hline 1 &, $924^{\mathrm{a}}$ &, 855 &, 834 &, 557 \\
\hline
\end{tabular}

a. Predictors: (Constant), Birokrasi, Fasilitas, Utilitas, Fisik_Kota, Ekonomi, Kualitas_Lk., Aksesbilitas, Sosial

\begin{tabular}{l|l|r|r|r|}
\multicolumn{7}{|c|}{ Model Summary } \\
\hline Model & R & R Square & $\begin{array}{c}\text { Adjusted R } \\
\text { Square }\end{array}$ & $\begin{array}{c}\text { Std. Error of } \\
\text { the Estimate }\end{array}$ \\
\hline 1 &, $913^{\text {a }}$ &, 833 &, 802 &, 668 \\
\hline
\end{tabular}

a. Predictors: (Constant), Birokrasi, Kualitas_Lk., Aksesbilitas, Ekonomi, Fasilitas, Sosial, Utilitas, Fisik_Kota

Source: Research Results, 2018 (IBM SPSS Statistics 22)

Based on Table 8 shows that the locus of Banyuasin Regency has an $\mathrm{R}$ value of 0.924 which means that the influence of eight independent variables, namely the physical city, environmental quality, facilities, utilities, economy, social and bureaucracy jointly on the implementation of sport events is very strong. While the value of $\mathrm{R}$ Square of 0.855 means that eight independent variables have an effect of 85.5 percent and the remaining 14.5 percent is influenced by other factors outside the object of research at the Banyuasin Regency locus.

Table 8 also shows that the locus of Ogan Ilir Regency has an $\mathrm{R}$ value of 0.913 , which means that the influence of eight independent variables, namely the physical city, environmental quality, facilities, utilities, economy, social and bureaucracy together on the implementation of sport events is very strong. While the value of $\mathrm{R}$ Square of 0.833 means that the eight independent variables have an effect of 83.3 percent and the remaining 16.7 percent is influenced by other factors outside the object of research at the locus of Ogan Ilir Regency.

\section{RESULT}

Based on the results of partial hypothesis testing of the eight independent variables covering city physical, environmental quality, accessibility, facilities, utilities, economy, social and bureaucracy, it is known that at the Banyuasin Regency locus, city physical variables, accessibility, utility, economic, social and bureaucratic does not have a significant influence on the implementation of sport events in South Sumatra Province, while the other two variables namely environmental quality and facilities have a significant influence on the implementation of sport events in the Province of South Sumatra. Of the two variables, the variable quality of the environment has the most significant level of influence on the implementation of sport events, which is also supported by 53.03 percent of respondents' positive responses. Then the facility variable is a variable that also has a significant degree of influence on the implementation of sport events, supported by 57.07 percent negative responses.

Based on the results of partial hypothesis testing of the eight independent variables covering the city physical, environmental quality, facilities, utilities, economics, social and bureaucracy, it is known that at the Ogan Ilir Regency locus, city physical variables, environmental quality, facilities, economic, social and bureaucratic does not have a significant influence on the implementation of sport events in the Province of South Sumatra, while the other two variables, namely accessibility and utility have a significant influence on the implementation of sport events in the 
Province of South Sumatra. Both of these variables have a significant level of influence close to the same as the implementation of sport events, where each variable is supported by 50 percent of respondents' positive responses.

Based on the results of the research and discussion, it was drawn as follows:

1. From the eight independent variables of the study, there were two variables at the Banyuasin Regency locus, namely the quality of the environment and facilities that had a significant influence on the holding of sport events. This has been proven by testing the significance of individual parameters and strengthened by the results of the variable description analysis, concluding that the two variables have a significant effect and are directly proportional to the implementation of sport events in South Sumatra Province.

2. From eight independent variables of the study, there were two variables at the Ogan Ilir Regency locus, namely accessibility and utility which had a significant influence on the sporting event. This has also been proven by testing the significance of individual parameters and being strengthened by the results of variable description analysis, concluding that the two variables have a significant effect and are directly proportional to the implementation of sport events in South Sumatra Province.

3. The main improvements to environmental quality variables are focused on indicators is at the Banyuasin Regency locus

a. Availability of green open space

b. Waste management efforts

c. Reduction of air pollution
For facility variables, improvements focus on indicators:

a. Information on recreational locations

b. Empowerment of city parks

c. Limitations of public transportation

At the Ogan Ilir Regency locus, major improvements to the accessibility variable are focused on indicators:

a. Ease of access in and out

b. Location travel time suitability

c. Efforts to maintain road conditions

For utility variables, improvements are focused on indicators:

a. Availability of clean water

b. Stability of electric power

c. The quality of telecommunications signals

\section{REFERENCES}

[1] Nurfaedah, Ulfi. (2015). Analisis Peran Kota Tangerang sebagai Kota Satelit Jakarta (studi kasus: transportasi komuter tangerangjakarta) http://digilib.esaunggul.ac.id/bookmark/ 5292/kota\%20satelit

2] Cities Alliance, W. (2007). Liveable cities: the benefits of urban environmental planning: a cities Alliance study on good practices and useful tools.

[3] Kaplanidou, K., \& Vogt, C. (2010). The meaning and measurement of a sport event experience among active sport tourists. Journal of Sport Management, 24(5), 544-566.

[4] Kennedy, D. (2009). The spectator and the spectacle: audiences in modernity and postmodernity. Cambridge University Press. 